\title{
Social Policies and Structures: Institutional Frictions and Traps in the Czech Republic After 1989
}

\author{
By: Jiři Večerník
}

William Davidson Working Paper Number 404

November 2001 


\title{
Social Policies and Structures: Institutional Frictions and Traps in the Czech Republic After 1989
}

\author{
Jiri Vecernik \\ Institute of Sociology, Academy of Sciences \\ Jilska 1, 11000 Praha 1, Czech Republic \\ e-mail: vecernik@soc.cas.cz
}

\begin{abstract}
This paper compares the standard economic and a complementary socio-economic approach to the transition. While the economic approach looks at social problems from the outside and views them as costs of transition, the socio-economic approach looks at these problems from the inside and views them as a part of the changing social structure. Both approaches are used to analyze four frictions which appear in contemporary Czech society. The first friction concerns the pension system which produces direct intergenerational dependence and turns pensioners into a socially needy population. It produces a socio-political redistributional trap, strengthening political support for further redistribution. The second friction concerns the relation between low market wages and a higher guaranteed subsistence minimum. It opens a socio-cultural trap and leads to a benefit dependency. The third friction concerns the impeding development of the middle class. Here, a socio-economic trap appears: a socially polarized society cannot take full advantage of its human capital and entrepreneurial spirit. The fourth friction involves tensions between various sections of the middle class. The socio-structural trap of unbalanced dynamics inside the middle class may cause an autonomous corporatization of individual groups to the detriment of citizenship principles and social integration.
\end{abstract}

Key words: distributional conflict, middle classes, pension reform, unemployment, Czech Republic

JEL Classification: P26, J23, J26, H31 


\section{Non-technical Summary}

This paper compares the standard economic and a complementary socio-economic approach to the transition. While the economic approach looks at social problems from the outside and views them as costs of transition, the socio-economic approach looks at these problems from the inside and views them as a part of the changing social structure. Both approaches are used to analyze four frictions which appear in contemporary Czech society.

1. Pensioners "against" the economically active. From an economic point of view, the unresolved situation of pensioners can undoubtedly lead to a fiscal crisis of the post-communist state. From a socio-economic point of view, however, we should describe also the socio-political redistribution trap. If the pension system rests only on intergenerational solidarity and if the social position of pensioners rests only on redistribution, then their political support - in contrast to its current diversification - will focus on the "socialist pole" of the political spectrum, supporting additional redistribution with all its adverse consequences. The solution is the diversification of pension funding, including a pronounced capitalization of insurance payments, whether in public or private institutions.

2. Non-working poor "against" low-paid workers. The inconsistency between the meager income derived from low wages and the relatively more comfortable social support indicates that the sociocultural level of society is higher than the actual performance of the economy. From the perspective of the labor market, it creates a dangerous unemployment trap which facilitates exit from the active labor force. From an employer's perspective, it weakens the undoubtedly desirable wage restraint, fed by the excess of labor supply over demand. At the same time it also creates a socio-cultural trap in the production and reproduction of social exclusion leading to increasing dependency on benefits. The solution is the use of activation and workfare, i.e. making the activity of the unemployed person into a relevant criterion for benefit entitlement.

3. Middle class "against" other groups. The middle class has considerably benefited during transition in gaining entrepreneurial and education freedoms, as well as a much larger space for the use and development of their skills. However, in comparison with expectations, their dynamism has been restricted. This may have significant consequences for future social stratification: while the upper classes will capitalize on their advantages and the poor will continue to be well protected at the subsistence minimum, the middle class will struggle through with difficulty. Then, even though the class of "truly poor" people remains small, a socio-economic trap may arise in the form of social polarization because some parts of the middle class will approach the poverty line. As a result, the transition can end in midcourse, since a divided society cannot take advantage of its educational, entrepreneurial, and labor potential.

4. Tensions between distinct sections of the middle class. The current states of individual branches within the tertiary sector differ, mostly due to policies applied early in the transition. The result is a very unequal position and uneven dynamic in individual sections of the middle class. Small business in the Czech Republic, in comparison with those in developed countries, live a hand-to-mouth existence. The socio-structural trap of unbalanced development inside the middle class can lead to an autonomous corporatization of individual sectors. This means that the middle class would no longer rely on the trickle-down effect, but would take advantage to a greater extent of corporatist instruments in putting forth their demands. 


\section{Introduction}

Social problems exposed or induced by transition from a communist regime to a democratic society are a challenge to social research and political decision-making. Of course there are numerous options in both the approach to these problems and the concrete policies chosen to address them. Usually, the simple calculation of economic costs prevails. However, it can be useful to look at social problems less in terms of gains and losses and more in terms of the relevant social actors, their networks and long-term development of the social structure. It is important to consider not only quantitative financial and other economic costs, but also qualitative changes in social relations. These include frictions, cleavages and latent conflicts which society creates by adopting or failing to adopt certain policies.

In some sense, most problems are legacies of the previous regime which have not been addressed energetically enough after 1989, or sometimes have not been recognized at all. Often, the inheritance of the past strengthens pressures to duplicate the overgrown welfare states found in wealthier economies. Politicians did not exploit the enormous political capital flowing from the liberalization of society and facilitate public acceptance for the dismantling of former expectations and structures. As a result, the period of post-communism is being inestimably prolonged. On the one hand, euphoria from the power that fell into its lap evaporates the "elite's" will to undertake thorough reforms of the economy and society. On the other hand, the "people's" dissatisfaction with the slow pace of change undermines their confidence in the efficiency of the new regime and the competence of political leaders.

This paper examines four types of socio-economic friction:

1. Pensioners "against" the economically active. The fact that old-age security is exclusively a matter of redistribution handled by the state relegates pensioners to the status of socially needy (poor) and pits them against the economically active population.

2. Non-working poor "against" low-paid workers. The fact that social benefits are higher than the minimum wage (and the lowest wages) forces unskilled workers outside the labor market and creates an unemployment and poverty trap.

3. Middle class "against" other groups. The expansion of the middle class has been hindered during transition by weak support for small businesses on the one hand and by limiting recovery of key sections of white collars.

4. Sections of the middle class "against" one another. People working in the financial sector and top state bureaucracy have an advantage over those in the human capital services, and the selfemployed enjoy more favorable conditions than employees.

Though this is certainly not an exhaustive enumeration of problems in the transitional social structure, significant focal points of tension are typically covered: intergenerational and institutional, as well as tensions in vertical social stratification and horizontal social structure. When we use the word "against" to describe these frictions, it is not meant to account open conflicts, but rather to draw attention to divergent socio-economic interests. These interests are often institutionally based and thus can persist for a long time and have a tendency to intensify over time. They prefigure the shape of social stratification patterns that may emerge and, eventually, problems in social cohesion which may have far-reaching consequences for economic growth and social development.

Before we consider these types of friction, though, we will first demonstrate the distinctiveness of our approach, which might be called "socio-economic" as opposed to the standard economic one. 
However, these two should not be seen as mutually exclusive alternatives. Rather, the socioeconomic approach supplements and enhances standard interpretations with insights into social structure. The next section describes the individual frictions in more detail. In the concluding section, we summarize again how these four areas of tension relate to policy-making.

\section{Economic and socio-economic approaches}

The end of the command economy and paternalistic communist policies has brought opportunities for socio-economic promotion to many, but also economic difficulties for large sections of the population. The whole social landscape is in flux. With increasing income inequality during transition, we ask who gains and who loses, and how differently individuals and households respond to new challenges. We also observe the reactions of policies to emerging problems and ask how effectively they deal with these problems. We compare different policies with Western models both in their costs and in the effects of interventions in the economy, whether favorable (increasing incentives to work and conduct business) or unfavorable (abuse of benefits, poverty traps and moral hazards).

Although it is affected by path dependence (Stark, 1992), the post-communist transformation differs in most respects from a naturally continuous historical process. In reform countries, transformation entails a radical intervention in which the centralized system is dismantled, the field of policy shrinks, and one set of policies is replaced by another within a transforming political and economic framework. This differs from the experience of non-transition societies in which gradual changes in the social structure create social problems that afterwards become the object of specific social policies. Gösta Esping-Andersen has demonstrated that welfare regimes are defined not only quantitatively by the extent of their relevant expenditures, but also qualitatively by divergent class interests lobbying for distinct social policies (Esping-Andersen, 1990).

And as Karl Polanyi (1957) documented, even the establishment of "laissez-faire" capitalism was anything natural. Nevertheless, policies in the 19th century usually played a corrective role, as opposed to the post-communist transformation in which the role of policy is foundational. A new structure of ownership, distribution of income and institutions are formed from above through an exclusively political process. However, no "tabula rasa" is available here. Transformation takes place in a society permeated by social ties and networks from the past and in an environment full of vested interests as well as old modes of conduct. The "velvet" character of the Czech revolt transition allowed these networks to stay active, and many of the stakes to remain in place. Moreover, the weak political will to enforce new rules has allowed insiders to effectively influence both the dispersion of massive amounts of property and the functioning of new institutions.

In such an extraordinary situation the original historical sequence "social structure-social problemssocial policies" is reversed: the former system is dismantled precisely by political instruments (including economic and social policies), while at the same time other policies react to the problems thus created. A "side effect" of this process is the transformation of the social structure, which can then mitigate or exacerbate old problems and either generate new problems or prevent their emergence. The study of these replacements, conversions, adjustments and modification is a long process and requires a combined economic, sociological and political analysis.

In the last few years, important studies of institutions and social structures have been made, partly in response to simplistic economic explanations and the real failures of macroeconomic recipes. Among the most important of these were the institutionally-oriented study made by Jon Elster, Claus Offe and others about "rebuilding the ship at sea" (Elster, Offe and Preuss, 1998) and the 
social structural study made by Ivan Szelenyi and his colleagues on "making capitalism without capitalists" (Eyal, Szelenyi and Townsley, 1998). An area of special interest is the political and institutional background of social policy in general and of pension reform in particular (Cook, Orenstein and Rueschemeyer, 1999; Orenstein, 2000; Müller, 1999). Another significant strand in this literature concerns the economic and social position of the middle class (Landes, 1998; Adelman and Morris, 1967; Kreml, 1967; Tilkidjiev, 1998; Easterly, 2000).

\section{Scheme 1}

In this study, we look at problems in Czech society through a comparison of two approaches (Scheme 1). In the standard economic approach, social problems are considered as the price paid for reforms. These problems can be enumerated and their costs at least partially quantitatively estimated. Here the transition is seen from the outside, particularly from the perspective of the rupture which it produces. In the wider socio-economic approach we look at ongoing change from inside the society, particularly from the perspective of the continuity the transition enables. Here, the qualitative transformation of the social structure is more important than quantitative criteria. In the language of the new economic sociology, it is a matter of the "embeddedness" or "encapsulation" of economic behavior in the social structure (Granovetter, 1985; Etzioni, 1988). As in Amitai Etzioni's understanding, these two approaches are not antithetical but complementary.

From the perspective of the continuously changing social structure, social problems not only constitute deficiencies originating at the margins of the system; they are also in some sense attributes of its content. The main "social problem" could thus be the social structure of a society itself if lasting or intensifying tensions are built into its very core. Because this structure is no longer repressed by state force as in the communist regime, latent conflicts can occasionally flare up. Short-term policies which address effects instead of causes can unintentionally contribute to undesirable changes in the social structure, which can eventually create bigger problems with an even more severe impact. If the social dynamic does not rest on a coherent and stabilizing social structure, the merry-go-round of partial and short-term policies will continue to turn.

\section{Four traps}

\subsection{Pensioners "against" the economically active}

In a PAYG system pensioners are paid from the contributions of the economically active. However legitimate such a contract of intergenerational solidarity may be, it necessarily conceals latent conflicts. These arise from the fact that one group has to pay for another, and from the tension between the certainty of current payments and the uncertainty of future benefits. Figuratively speaking, PAYG is a traditional "working class mechanism" (in my old age my children will support me) as opposed to a modern "middle-class mechanism" (in my old age I will live from the yields of my business, property or savings). The system does not take advantage of the modern economy which allows the capitalization of savings and a worldwide diversification of risk.

This flow of money, formerly hidden in the general redistribution under communism, is laid bare in an open democratic system. Redistributional pressure, which is built into the system, is strengthened by two trends that Czech society shares with advanced Western countries: a decreasing fertility rate and increasing life expectancy. Together with the decline in employment, both trends contribute to the need for increasing redistribution in the future. The excessive burden on the active population provokes attempts to avoid the tax burden by exiting to the haven of the 
informal economy. This leads to a reduction in the number of contributors and revenue collected and thus to pressure to raise the contribution rate.

To date, significant, though not fundamental changes in the pension system have taken place in the Czech Republic. The early (1990-1991) reforms involved the abolishment of pension privileges and the introduction of regular valorization instead of ad hoc increases. The later (1994-1995) set of reforms brought about voluntary pension savings with a state subsidy and a gradual increase in the retirement age. Regular valorization speeded up the growth of pensions to such an extent that in the period 1990-1992 the relative position of pensioners in the income distribution improved. While in the period 1993-1996 the growth of pensions more or less followed the growth of wages, by 1997 the rules of valorization were weakened and the average pension again began to drop in relation to the average wage (Figure 1).

\section{Figure 1}

The relation between wages and pension benefits indicates underlying problems and gloomy prospects. While at the beginning of the 1990s the pension system boasted a surplus, in recent years this trend has reversed. Demographers predict an increase in the proportion of persons over 60 years of age from 19 percent in 2000 to 23 percent in 2010 and 27 percent in 2020 (Kucera, 1999). Though this dire prediction has stimulated some debate about fundamental reform of the pension system through the creation of a "second pillar" of mandatory private insurance, the self-declared "liberal" government did not undertake any serious steps towards that goal and continues to rely solely on voluntary savings. The new social democratic government (1998-2002) has refused any move in this direction and wants only to reform the PAYG system by creating notional individual accounts with defined contributions.

Parametrical changes in the pension system and the conceived creation of an independent public "insurance company" will do little to contribute to the socio-economic emancipation of pensioners when the pensioners remain exclusively dependent on the active population. This, in turn, means that the real income of the active population may partly depend on the proportion of pensioners in the society and the generosity of the state in setting the average wage/pension benefit ratio. A large number of people save privately for retirement, but due to low average contributions, these savings can only hardly change the financing of pension benefits in a significant way. Active earners and pensioners will thus remain connected at the hip, and a latent social conflict will continue to develop between the two generations.

The socio-structural arrangement of the communist regime thus continues as retirement brings a shift into another "social category" (instead of "emeritus" status) with far-reaching consequences for people's living standards and lifestyles. Pensioners argue that the purchasing power of their benefits is decreasing while the gap between the average wage and benefits is increasing. However, any concession to their demands aggravates the payroll burden for the economically active population, and the edges of the tension between the two social categories thus sharpen. The situation worsens if the relationship is simplified in the public's mind into an imaginary trade-off between benefits for pensioners and children.

\subsection{Non-working poor “against” low-paid workers}

After 1989, poverty remained very low in the Czech Republic (Table 1) because it used to be largely a matter of the so-called "old poverty" connected with the life cycle of the family and affecting mainly households with a large number of children, or the elderly living alone. On the 
other hand, so-called "new poverty" resulting from labor market failures also remains low. Even though the status of being unemployed is a very strong factor in income inadequacy in most individual cases, low overall unemployment has resulted in a low level of poverty. However, since 1997, unemployment has experienced a significant increase which has affected the poverty rate. Therefore, one should turn attention to the institutional frame and specifically, to a mismatch between the subsistence minimum and low wages creating substantial unemployment and poverty traps.

Table 1

A subsistence minimum was newly established by law in the Czech Republic in 1991 and serves as the legal poverty line. This legislation gives households with very low incomes an entitlement to social benefits after a (not very rigorous) testing of their income situation and property holdings. The state support benefits are indexed against the consumer price index. The rules for determining the subsistence minimum have remained almost intact from the previous regime. They are based on the principle of individual basic needs and take little account of the shared needs of households and of scale economies. Benefits thus calculated are therefore advantageous for large households and disadvantageous for small families and single persons. Because the share of family expenditures on foodstuffs is declining and the share on housing rising, this imbalance is strengthening.

While the subsistence minimum in a form was applied even before the reforms, a minimum wage was first established in the Czech Republic in 1991 and set at a level of 2000 CZK (53 percent of the average wage). Soon after it was raised to 2200 CZK and then was frozen until 1996. Its longterm nominal stagnation and real fall was an escape from the dilemma of the governing "liberals" who considered the minimum wage inappropriate to a free market economy but had to respect already ratified international agreements that guaranteed its existence. It started to rise again in 1996 and was last increased in January 2000 to 5000 CZK (39 percent of the average wage) and thus finally crossed the level of the subsistence minimum for a single person. However, benefit dependency still remains advantageous for about five percent of workers, mostly those with larger families.

\section{Table 2}

The net replacement rate of wages by social benefits in the Czech Republic is as high as in the most generous European countries where social benefits can fully replace average earnings of production worker having a family (Table 2). The distance between the relatively generous (especially for large families) and steadily valorized subsistence minimum on the one hand and low and stagnating wages for lower categories of workers on the other creates a relatively inviting poverty trap (Figure 2). This state of affairs is mainly advantageous for Roma families, where the number of children is usually high and employability low. Furthermore, this trap is similarly attractive for rural households where living costs are low due to considerable income in kind, while expenditures connected with employment are high due to greater transport costs.

Figure 2

Apparently, the socio-cultural expectations of society, whether set by previous redistribution policies or identification with Western models, are higher than the performance of the economy allows. A simple remedy of course is to administratively hold wages above the level of social benefits. However, this also has creates a series of adverse effects: it increases the costs of unskilled labor above the market price. Thus, employers are reluctant to hire less-skilled workers and try to 
replace them with technology or, more often, undemanding illegal workers (typically Ukrainians). Because higher wages for lower categories of workers result in relatively lower wages for higher categories, the wage hierarchy shifts upwards, thus increasing wage inflation.

In a certain sense, this is an inheritance from the communist "premature welfare state" (Kornai, 1995:131) but under communism work was compulsory for all and thus no unemployment trap or benefit dependency could appear. At the same time, the shame of unemployment and rent-seeking, formerly rooted in Czech middle-class society, disappeared and people followed the catchphrase "he who does not steal, robs his family" which spread under communism. A combination of generous state benefits and bad individual morale resulted in massive abuse of the welfare system. Thus, placing emphasis on activation policies, i.e. making social benefits depend on the activity of the unemployed (searching for a job, training and re-training, taking temporary jobs) appears to be a necessity.

Unlike the lively debate that has been taking place on workfare and other labor activation measures in Western Europe (Lind and Hornemann Möller, 1999), issue has thus far hardly been mentioned in the Czech Republic, and has moreover been explicitly rejected by leading social democratic politicians. Therefore, at the dark margin of the social structure, "clever" benefit recipients will remain opposed to "dull" low-paid workers, giving them lessons in how to behave in distorted institutional settings on the margin between economic and social sphere. The invitation into generous arms of the post-communist welfare state is tempting for an increasing number of people.

\subsection{Middle class "against" other groups}

Rather than perpetuating the simplifying and misleading - however common - division of poor and rich we should try to see society's stratification patterns in a more complex way. The central social group in every modern society is a diversified middle class. William Easterly finds that the strength of the middle class predicts social cohesion, political stability and economic growth (Easterly, 2000). For these reasons the restoration of standard modern society in the Czech Republic should lead to the reconstitution of this class, and vice versa (Mateju, 1999; Vecernik, 1999a). This is supported by the fact that the Czech nation lacks an important gentry and bourgeoisie on the one hand, and retains a strong social feelings on the other (Vecernik, 2000).

Surprisingly enough, until now the agenda of creating and developing a strong middle class in the Czech Republic has not been addressed in a positive way by politicians. According to the liberal rhetoric dominating in the first half of 1990s, social protection has to be reserved only for the poor while others are the "rich" upon whom progressive taxation is legitimately imposed. In support of this point, policy-makers cited the argument of R.E. Goodin and Julien Le Grand (1987) that social redistribution is directed mainly from low-income to high-income groups through state expenditures on education, transport, and other services. According to the socialist rhetoric that gained currency in the second half of 1990s, there are no middle classes in Czech society, only the "lower ten millions" and policies should only be implemented if they benefit all.

The question is not, however, how to redistribute in favor of the middle class, but how not to redistribute too much to its detriment. Income surveys from the 1988-1996 period show that inequality in household incomes increased, especially as a result of growth in the highest-income group. Low-income groups suffered the greatest losses in purchasing power, followed immediately by those with above-average middle incomes. Greater redistribution through taxes and benefits (as a result of a more progressive personal income tax and more targeting of social transfers) especially hit the middle categories. Larger transfers to the lowest income groups hit more middle income 
categories than higher ones. While the amount of taxes paid by the lowest-income groups decreased significantly, the amount paid by middle-income categories increased (Vecernik, 1999a).

Such developments contrast with the program recommended by Walter Korpi and Joakim Palme. As their comparative analysis of protection systems has shown, redistribution from rich to poor in "residual" welfare states, targeting only the poor and offering flat benefits, has a relatively weak leveling effect on income distribution. On the contrary, the best results have been achieved by universal mandatory insurance systems offering benefits differentiated by income. This is true not least because the legitimacy of redistribution in such a system is stronger; as a result the total amount of redistribution can also be greater. Since individuals are guaranteed a return on taxes paid, the disincentive effect of the tax burden also declines (Korpi and Palme, 1997).

Not only the tax burden of employees, but also the payroll tax for employers is rather large in the Czech Republic. The comparison show that only employers in Sweden and Italy pay more than 35 percent in payroll taxes (Figure 3). If we compare the entire "tax wedge", the Czech Republic finds itself above the average OECD country, though not at the very top (the heaviest burdens are in Hungary and Poland, but escape through the informal economy is also more significant in these countries). Nevertheless, a large gap of 10-15 percent separates the Czech Republic from the genuinely liberal countries of the OECD such as Great Britain, Switzerland, USA, and to some extent Ireland. Another burden is imposed on house-owners by the state regulation of rents. As rent levels are only slowly adjusting to market prices, owners can hardly repair and modernize their houses, much less earn a profit.

Figure 3

All these circumstances are well reflected in self-ranking into social classes as provided by sociological surveys. After 1989, people rejected the former forced identification with the working class and joined the middle class - at least in their own minds. While in the first years of the transformations, over 60 percent of the population labeled themselves as belonging to the middle class, most of them later inclined towards the more realistic category of lower-middle class (Table 3). In subjective class identification, education surprisingly matters less than one's branch of activity, which reflects the actual income hierarchy: teachers and researchers occupy much lower positions than lawyers, bank officers and economic consultants.

Table 3

The decline of middle-class identification has many objective causes. Beside income position there is also dissatisfaction with large-scale privatization. The voucher method was originally presented as a lesson in capitalist investment and was to have created the nation's middle class. Actually, it became a channel for converting national property into immediate consumption for many and a tool of enrichment for a few. Because of some people's desire to quickly enrich themselves within a context of generally poor business ethics, many companies that were privatized into Czech hands lived only as long as the generous hand of semi-state banks supported them, and finally went bankrupt (Mlcoch, 1995; Vecernik, 1999b).

Table 4

Self-ranking among the middle class is closely connected with the feeling that privatization has brought personal gain, holding shares instead of selling immediately, and opting for company shares rather than Investment Privatization Funds shares (Table 4). As most individual "investment 
strategies" have since failed and all remaining company shares (even those of banking giants) have turned out to be nearly worthless by the end of the 1990s, the perceived legitimacy of privatization is obviously vanishing. The two trends thus strengthen each other: decreasing allegiance to the middle class and a declining confidence in pro-market changes among those who still identify with it. Over time, the middle class has also been following the general trend of declining support for liberal principles.

\subsection{Tensions between distinct sections of the middle class}

The middle class is not a homogeneous body, but is differentiated at least into the "old" middle class, occupied in the production and distribution of material goods and services, and the "new" middle class, occupied in the production and distribution of symbolic knowledge (Berger, 1986). As the first section disappeared completely during the communist regime (which was stricter in Czechoslovakia than elsewhere because of the former extent and power of the middle class), the second was suppressed and downgraded into a gray mass of employees. Both sections reappeared during transition, although at an uneven pace and retaining or even expanding their internal heterogeneity.

Conditions created after 1989 for new small and medium businesses in the Czech Republic are rather ambivalent. On the one hand, a large space was opened for, and little regulation applied to new businesses. However, endless amendments to businesses legislation bring about more instability than transparency into economic activity. On the other hand, former state firms were privileged, especially in access to credit and tolerance for non-payment of payroll taxes and other liabilities. Unlike the generous financing offered to the privatized companies, only little and occasional support was given to the de novo entrepreneurs.

In comparison with white-collar workers, the self-employed have two advantages. The first is legal. While the base for computing social and health insurance contributions among employees equals the entire tax base (i.e., the gross wage), it is only 35 percent of the tax base (i.e., net income) of the self-employed. The self-employed are thus eventually less burdened than employees. The second advantage is only semi-legal or even illegal. Self-employed persons have more liberty in tax setting and, even, are able to negotiate the boundary between the formal and informal economies or escape completely into the informal economy. In this way, they can successfully avoid paying considerable sums of taxes and insurance contributions.

Indeed, social and health insurance statistics show that while employees represent 39 percent of insured persons and that they pay as much as 63 percent of the total amount of contributions, the self-employed represent 9 percent of insured persons and pay only four percent of contributions. Moreover, 95 percent of the self-employed declare income lower than the average wage and half of them even declare a minimum income equal to 40 percent of the minimum wage (Pelc, 2000). The space given to the self-employed for avoiding taxes and contributions is thus quite large and is also actually used by Czech people, well trained in adaptive behavior during communist times.

Although the number of new businesses increased rapidly at first, this growth was far from an explosion. The majority of "independent" work is still done as a supplement to dependent activity, and so formally represents only secondary employment, though the effort devoted to it is often greater. Thus the boundary between the "old" and "new" middle class is often indistinct: according to statistics from the Ministry of the Interior, 1,700,000 entrepreneurs are registered, which contrasts with the Labor Force Survey finding only 700,000 employers and self-employed persons 
at the beginning of 2000. Therefore, somewhere around one million people (one-fifth of the labor force) share dependent and independent employment, combining the advantages of both.

Speaking of "winners" and "losers" of the transformation can be misleading, but these terms do describe several sections of the "new" middle class. The "financial bureaucracy" has especially done very well for itself. This once rank-and-file section of state administration changed practically overnight into an elite category in terms of remuneration and prestige. Although banks formally belong to the business sector, their connections to the state through ownership and the lack of managerial responsibility for losses justifies our speaking of "financial bureaucrats". As an illustration, the total amount of wages in the financial sector (average wage*personnel) represents already three quarters of the wage bill of healthcare personnel. Contrary to expectations, the administrative bureaucracy has also expanded both in number of employees and spending (Figure 4).

\section{Figure 4}

By contrast to the sectors of finance and public administration, public services attending to the reproduction and development of human capital (healthcare, education, research) fell noticeably behind. The expectation of a restoration of the pre-1948 status of these sectors remains unfulfilled. This especially pertains to teachers at all levels. While in the mid 1990s salaries in the educational system temporarily improved in relation to the national average, by 1997 they had returned to their initial level (88 percent of the average as of mid-2000). The maximum salary of a university professor (according to the wage grid) only slightly exceeds the average wage. Though the wage level of healthcare personnel increased at first and exceeded the wages of teachers, it dropped again to the same level (also 88 percent of the average as of mid-2000).

The aforementioned developments are not laid down in the "natural" or "market" order of things, but are the result of power relations, and in no small measure of specific policies, mainly those enacted at the beginning of the transition. If we view wages as the price of labor, we should take into account Amitai Etzioni's observation that the price reflects the costs of production "... and the relative economic and political power of producers (providers, sellers, etc.) compared with consumers (buyers, etc.) and other parties (government regulators, consumer unions, farm lobbies, etc.)" (Etzioni, 1988:256-257). Despite numerous declarations to the contrary, government policy has not been very well-disposed towards the interests of these groups. Thus the latent power remains on deposit - the corporate power of individual sections of the middle class the use of which can only lead to improvement of their income position in the society.

\section{Conclusion: transitional social structure and its traps}

Instead of witnessing energetic change, Czech society has maintained many of the former structures. Behind the facade of a liberal policy, strong actors have been supported and a high degree of redistribution maintained. Policies of granting generous credit to keep large firms afloat while exposing new firms to merciless competition have been at cross-purposes with the declared aim of creating a free market economy. Paternalistic employment (labor hoarding) in large firms, rent regulation (which favors citizens who obtained state apartments under communism), and generous social benefits nourished continuing expectations of state protection. The transformation of the social structure towards one that would favor the development of a middle-class has thus been considerably obstructed 


\section{Scheme 2}

If we return to our original dichotomy between the standard economic and the complementary socio-economic approach, we can now summarize the shortcomings and possible traps of social policies from both perspectives (Scheme 2).

Ad 1. Pensioners "against" the economically active. From an economic point of view, the unresolved situation of pensioners can undoubtedly lead to a fiscal crisis of the post-communist state (Campbell, 1992). From a socio-economic point of view, however, it is necessary to add something more - specifically, the socio-political redistribution trap. If the pension system rests only on intergenerational solidarity and if the social position of pensioners rests only on redistribution (whether through the state budget or through a centrally administered public fund), then their political support - in contrast to its current diversification - will focus on the "socialist pole" of the political spectrum, supporting additional redistribution with all its adverse consequences.

An effective strategy to deal with this problem would be to weaken what has been until now an almost exclusive dependence of pensioners on the economically active population and to strengthen the continuity of an individual's social status throughout his or her life cycle. In other words, in addition to the principle of mandatory intergenerational solidarity, it is necessary to build up the principle of individual responsibility. Only by strengthening the dependence of the social position of the elderly on their prior savings and accumulated property will it be possible to relieve pensioners (and especially their middle-class majority) of the unwarranted status of poor or socially needy. The solution is the diversification of pension funding, including a pronounced capitalization of insurance payments, whether in public or private institutions.

Ad 2. Non-working poor "against" low-paid workers. From a solely economic point of view, the inverted relation between the meager income derived from low wages or unemployment benefits and the relatively more comfortable income from welfare benefits (the subsistence minimum) is absurd (even though we cannot forget that we are comparing the situation of an individual with the situation of a family). This inconsistency indicates that the socio-cultural level of society is higher than the actual performance of the economy. In other words, the implemented "standard family budget" (OECD, 1998a) is not closely connected with the market price of labor.

This is how pressure for increasing social transfers originates. From the perspective of the labor market, it creates a dangerous unemployment trap which facilitates exit from the active labor force. From an employer's perspective, it weakens the undoubtedly desirable wage restraint, fed by the excess of labor supply over demand. At the same time it also creates a socio-cultural trap in the production and reproduction of social exclusion leading to increasing dependency on benefits which hits so far especially the unadaptable part of the Roma population. One possible solution is the use of workfare and activation, i.e. making the activity of the unemployed person into a relevant criterion for benefit entitlement.

Ad 3. Middle class "against" other groups. From the perspective of the state budget, it does not matter how and from whom financial resources for social transfers are collected. Modern economics nevertheless does care about work incentives and disincentives arising from specific protection schemes and the differentiated tax burden of employees and employers. However, the economics is only sporadically concerned with the growing transactions costs persisting in the formal economy and the "rate of return of illegality" (Prosi, 1997), i.e. the increasing potential for gains within the informal economy. The problem here is the absence of individual-level data. As a 
result, analysis is restricted to macroeconomic estimates and the essential dimension of differentiation and incentive structure is neglected.

Institutions develop and mature over the long term. This applies to the social structure and the position of the middle class as well. The middle class is not just a manifest consequence, but chiefly an important condition for a successful transition, and a guarantee of its permanence because it has a constitutive or integrating role in many areas of social and economic life. Its value system corresponds well to the needs of an open democratic society, and its central positioning between capital and labor ensures the integration of society: "The only alternative to a social structure founded on the existence and development of the middle class is drawing a sharp dividing line - ignominiously known from all totalitarian states - between rulers and ruled" (Johnson, 1998: back translated from Czech).

The middle class has considerably benefited during transition in gaining entrepreneurial and education freedoms, as well as a much larger space for the use and development of their skills. However, in comparison with hopes and expectations, their dynamism has been restricted. This may have significant consequences for future social stratification: while the upper classes will capitalize on their advantages and the poor will continue to be well protected at the subsistence minimum, the middle class will struggle through with difficulty. Then, even though the class of "truly poor" people remains small, a socio-economic trap may arise in the form of social polarization because some parts of the middle class will approach the poverty line. As a result, the transition can end in midcourse, since a divided society cannot take advantage of its educational, entrepreneurial, and labor potential.

Ad 4. Tensions between distinct sections of the middle class. The current states of individual branches within the tertiary sector differ, mostly due to policies applied early in the transition, or deliberate neglect of such policies. First, various sections of the middle class were able to take advantage of the political and social capital they accumulated under the communist regime. Moreover, the ideological context of the initial phase of the transition was biased. In the setting established after 1992, human capital was pushed into the background by financial capital and efforts to preserve the past outweighed attempts at change. The result is a very unequal position and uneven dynamic in individual sections of the middle class. Only after ten years of transition will the privatization of banking giants lead to staff cutbacks, wage restraint and the end of irresponsible crediting.

Reflections on the relation of large to small and medium business must be concluded with a question mark. Small business in the Czech Republic, in comparison with those in developed countries, live a hand-to-mouth existence. This could be due to weak support, selective credit policies, missing economic regulations, imbalance between creditors and debtors (which hampers small entrepreneurs far more than large ones) or behind-the-scenes economic power derived from continued networks and liaisons between political and economic clans. It looks as though the only small and medium-sized businesses to survive will be those connected to large enterprises and their cartels or to the state and its bureaucracy. Thus, they largely maneuver at the border of the formal and informal economies (Benacek, 1994).

The socio-structural trap of unbalanced development inside the middle class can lead to an autonomous corporatization of individual sectors. This means that the middle class would no longer rely on the trickle-down effect, but would take advantage to a greater extent of corporatist instruments in putting forth their demands. The dominant civic parties governing until 1997 (especially the Civic Democratic Party) have tried to prevent the self-organization of such groups 
and offered them only minimal bargaining powers. In contrast to their earlier general right-wing loyalty, it is likely that individual sections of the middle class will strengthen their existing associations or will form new corporatist bodies, making use of a greater range of chambers and unions which would ensure them better living standards through redistribution.

In modern society, redistribution is undoubtedly a necessity because it ensures social cohesion. During transition, however, it must remain within restricted limits in order not to hinder social change by distorting individual motivation and personal effort. The delineation of such limits cannot only result from a rational economic calculation, but should also involve consideration of the social structure, in its political, economic and cultural dimensions. Within each of these, the crossing of certain limits leads to another type of redistributional trap, but in the end to the same stagnation. To be a "working pensioner", welfare recipient active in the informal economy, or an employee running a moonlight business may be a good survival strategy for individuals, but certainly it is not a development path for an advanced society.

The "middle-class-matters" argument appears here again: "Countries with a middle class consensus are fortunate societies. They have a higher level of income and growth. We can see why relatively homogenous middle-class societies have more income and growth, because they have more human capital and infrastructure accumulation, they have better national economic policies, more democracy, less political instability, more 'modern' sectoral structure, and more urbanization" (Easterly, 2000:29). Will Czech society again be as fortunate as it was before the war when it belonged to a democratic and economically advanced country with a typical middle class social structure? 


\section{References}

Adelman, I. and Taft Morris, C. (1967) Society, politics, and economic development: a quantitative approach. Baltimore: Johns Hopkins Press.

Atkinson, A.B., Rainwater, L. and Smeeding, T.M. (1995) Income Distribution in OECD Countries. Evidence from the Luxembourg Income Study. Paris: OECD.

Berger, P.L. (1986) The Capitalist Revolution. Fifty Propositions about Prosperity, Equality and Liberty. New York: Basic Books.

Benacek, V. (1994) Small business and private entrepreneurship during transformation: The case of the Czech republic. Working Papers No. 53. Prague: CERGE/EI.

Campbell, J.L. (1992) The fiscal crisis of post-communist states. Telos 93.

Cook, L.J. Orenstein, M.A. and Rueschemeyer, M. (1999) Left Parties and Social Policy in Postcommunist Europe. Boulder, $\mathrm{CO}$ and Oxford: Westview Press.

Easterly, W. (2000) The middle class consensus and economic development. The World Bank Working Papers No. 2346.

Elster, J., Offe, C. and Preuss, U.K. (1998) Institutional Design in Post-communist Societies. Rebuilding the Ship at Sea. Cambridge: Cambridge University Press.

Esping-Andersen, G. (1990) The Three Worlds of Welfare Capitalism. Cambridge: Polity Press.

Etzioni, A. (1988) The Moral Dimension. Toward a New Economics. New York: The Free Press.

Eyal, G., Szelenyi, I. and Townsley, E. (1998). Making Capitalism without Capitalists. The New Ruling Elites in Eastern Europe. London and New York: Verso.

Goodin, R.E. and Le Grand, J. (1987) Not Only the Poor. London: George Allen \& Unwin.

Granovetter, M. (1985) Economic action and social structure: the problem of embeddedness. American Journal of Sociology, 91(3):481-510.

Johnson, P. (1998) Enemies of Society. London: Weidenfeld \& Nicholson.

Kornai, J. (1995) Highways and Byways. Studies in Reform and Post-Communist Transition. Cambridge and London: MIT Press.

Korpi, W. and Palme, J. (1997) The paradox of redistribution and strategies of equality: welfare state institutions, inequality and poverty in the Western countries. American Sociological Review 63 (October): 661-668.

Kreml, William P. 1997 America's Middle Class: From Subsidy to Abandonment. Carolina Durham NC: Academic Press.

Kucera, M. (1999) Pensioners from a demographer's viewpoint (Manuscript, in Czech).

Landes, David. (1998). The Wealth and Poverty of Nations. New York: Norton.

Lind, J. and Hornemann Möller, I. (1999) Inclusion and Exclusion: Unemployment and Nonstandard Employment in Europe. Aldershot: Ashgate.

Mateju, P. (1999) The renewal of the middle class and its political circumstances. In: Vecernik and Mateju eds. 1999.

Mlcoch, L. (1995) The restructuring of property rights through the institutional economist's eyes, Prague Economic Papers 4: 148-158.

Müller, K. (1999) The Political Economy of Pension Reform in Central-Eastern Europe. Cheltenham: Edward Elgar.

OECD (1997) The Tax/Benefit Position of Employees 1995-1996. Paris: OECD.

OECD (1998a) The Battle against Exclusion Vol. 2. Social Assistance in Belgium, the Czech Republic, the Netherlands and Norway. Paris: OECD.

OECD (1998b) Benefit System and Work Incentives. 1998 Edition. Paris: OECD. 
Orenstein, M. (2000) How Politics and Institutions affect pension reform in three postcommunist countries. Policy Research Working Papers No. 2310. Washington: The World Bank.

Pelc, V. (2000) Will employees further pay for entrepreneurs? (in Czech) Pohledy 8 (3-4):30-34.

Polanyi, K. (1944) The Great Transformation. The Political and Economic Origins of Our Time.

Boston: Beacon Press.

Prosi, G. (1997) Economic limits for the welfare state. Paper presented on the International seminar of the welfare state in post-communist Europe. Prague: CEU.

Stark, D. (1992) Path dependence and privatization strategies in East Central Europe. East European Politics and Societies 6 (1):17-51.

Tilkidjiev, N. ed. (1998). The Middle Class as a Precondition of a Sustainable Society. Sofia: Association for Middle Class Development.

Vecernik, J. (1996) Markets and People. The Czech Reform Experience in a Comparative Perspective. Aldershot: Avebury.

Vecernik, J. (1999a) The middle class in the Czech reforms: the interplay between policies and social stratification. Communist and Post-Communist Studies 32 (4):397-416.

Vecernik, J. (1999b) Capitalist renewal and privatization. In: Vecernik and Mateju eds. 1999.

Vecernik, J. and Mateju, P. eds. (1999) Ten Years of Re-building Capitalism. Czech Society after 1989. Praha: Academia.

Vecernik, J. (2000) Rise, fall and recovery of the Czech middle class (in Czech). In: Co daly nase zeme Evrope a lidstvu. Praha: ELK.

\section{Data sources}

Microcensus. Large income surveys started in 1958 as regular statistical surveys conducted every 3-5 years on 1-2 percent samples of households. Data on wages were notified by employers and pension benefits by post-offices. Here, we used the 1989 Microcensus conducted by the CSO on a 2 percent random sample $(\mathrm{N}=69,912)$ in March 1989 including yearly incomes in 1988, the 1992 Microcensus, conducted by the CSO on a 0.5 percent random sample $(\mathrm{N}=16,234)$ in March 1993 and including yearly incomes in 1992, and the 1996 Microcensus, conducted by the CSO on a 1 percent random sample $(\mathrm{N}=28,148)$ in March 1997 and including yearly incomes in 1996. In the two later surveys, incomes were not confirmed but data corrections were made by the CSO.

Economic Expectations and Attitudes. The surveys of the Czechoslovak and later only Czech population started in May 1990 and were conducted biannually in 1990-1992 and later annually (1993-1998). Surveys were organised by the team of socio-economics of the Institute of Sociology of the Academy of Sciences headed by Jiri Vecernik. The samples include adults selected by a twostep quota sampling procedure, whereby the region and size of the locality were defined in the first step and gender, age and education in the second. The data was collected by the Center for Empirical Research STEM. Survey data are available in Sociological Data Archive on http://archiv.soc.cas.cz.

Social Justice. International research project on which 14 countries participated in 1991. It was repeated in several transition countries only in 1995. In the Czech Republic, the basic set of questions was included again in International Social Survey Program module "Social inequality" in 1999. Individual samples involve 810 adult respondents for 1991, 1246 for 1995 and 1834 for 1999. The data was collected by the Center for Empirical Research STEM. Survey data are available in Sociological Data Archive on http://archiv.soc.cas.cz. 
Scheme 1 Two views of socio-economic transformation

\begin{tabular}{|c|c|c|}
\hline Area & $\begin{array}{l}\text { Standard } \\
\text { economic approach }\end{array}$ & $\begin{array}{l}\text { Complementary } \\
\text { socio-economic approach }\end{array}$ \\
\hline View of social problems & costs of transition & $\begin{array}{l}\text { components of social } \\
\text { change }\end{array}$ \\
\hline Point of view & from the outside & from the inside \\
\hline Criteria & quantitative & qualitative \\
\hline History & $\begin{array}{l}\text { discontinuity } \\
\text { (individual reform steps } \\
\text { ending at a certain point) }\end{array}$ & $\begin{array}{l}\text { continuity } \\
\text { (path dependence, never } \\
\text { ending story) }\end{array}$ \\
\hline $\begin{array}{l}\text { Location of social } \\
\text { problems }\end{array}$ & $\begin{array}{l}\text { at the margin of the } \\
\text { mainstream process }\end{array}$ & $\begin{array}{l}\text { in the core of the social } \\
\text { structure }\end{array}$ \\
\hline $\begin{array}{l}\text { "Natural state" } \\
\text { of the system }\end{array}$ & $\begin{array}{l}\text { equilibrium } \\
\text { (and its distortions) }\end{array}$ & $\begin{array}{l}\text { conflict of interests } \\
\text { (and resulting } \\
\text { compromise) }\end{array}$ \\
\hline Time horizon & short- and medium-term & long-term \\
\hline $\begin{array}{l}\text { Social structure } \\
\text { is viewed as }\end{array}$ & result of transition & $\begin{array}{l}\text { part and condition of } \\
\text { the social change }\end{array}$ \\
\hline $\begin{array}{l}\text { Economics } \\
\text { is conceived as }\end{array}$ & $\begin{array}{l}\text { formal } \\
\text { (rational choice) }\end{array}$ & $\begin{array}{l}\text { substantive } \\
\text { (institutionalized relations) }\end{array}$ \\
\hline $\begin{array}{l}\text { Economy } \\
\text { is understood as }\end{array}$ & $\begin{array}{l}\text { autonomous, independent, } \\
\text { ruled by its own logic }\end{array}$ & $\begin{array}{l}\text { encapsulated (embedded) } \\
\text { in social structure }\end{array}$ \\
\hline $\begin{array}{l}\text { Shape of the } \\
\text { social structure }\end{array}$ & $\begin{array}{l}\text { hierarchical strata } \\
\text { according to income }\end{array}$ & $\begin{array}{l}\text { conflicting groups } \\
\text { (classes, generations) }\end{array}$ \\
\hline $\begin{array}{l}\text { Sources and channels of } \\
\text { change }\end{array}$ & mechanisms (markets) & actors (social groups) \\
\hline
\end{tabular}


Scheme 2 Two views of social problems

\begin{tabular}{|l|l|l|}
\hline Kind of controversy & $\begin{array}{l}\text { Standard } \\
\text { economic }\end{array}$ & $\begin{array}{l}\text { Complementary } \\
\text { socio-economic }\end{array}$ \\
\hline $\begin{array}{l}\text { 1. Pensioners vs. } \\
\text { economically active }\end{array}$ & $\begin{array}{l}\text { Threat of fiscal crisis } \\
\text { of the state }\end{array}$ & $\begin{array}{l}\text { Socio-political trap, } \\
\text { support of } \\
\text { "redistributional parties" }\end{array}$ \\
\hline $\begin{array}{l}\text { 2. Working poor vs. } \\
\text { non-working poor }\end{array}$ & $\begin{array}{l}\text { Rise of wages, } \\
\text { wage equalization, } \\
\text { unemployment }\end{array}$ & $\begin{array}{l}\text { Socio-cultural trap, } \\
\text { strengthening of } \\
\text { "dependency status" }\end{array}$ \\
\hline $\begin{array}{l}\text { 3. Middle class vs. } \\
\text { other categories }\end{array}$ & $\begin{array}{l}\text { No focused analysis } \\
\text { (poor vs. rich vocabulary) }\end{array}$ & $\begin{array}{l}\text { Socio-economic trap, } \\
\text { vertical cleavages, } \\
\text { social polarization }\end{array}$ \\
\hline $\begin{array}{l}\text { 4. The "old" vs. "new" } \\
\text { middle class, bureaucracy } \\
\text { vs. human capital }\end{array}$ & $\begin{array}{l}\text { No focused analysis } \\
\text { (reference to market } \\
\text { forces) }\end{array}$ & $\begin{array}{l}\text { Socio-structural trap, } \\
\text { horizontal cleavages, } \\
\text { corporatism }\end{array}$ \\
\hline
\end{tabular}


Table 1 Poor households and persons by family status (percent)

\begin{tabular}{lrrrrrr}
\hline Family status & \multicolumn{3}{c}{ Legal poverty line } & \multicolumn{3}{c}{ EU poverty line } \\
\cline { 2 - 7 } & 1988 & 1992 & 1996 & 1988 & 1992 & 1996 \\
\hline Households: & 1.1 & 3.2 & 2.7 & 0.7 & 2.0 & 6.3 \\
Family with children & 8.1 & 10.2 & 8.3 & 5.0 & 7.5 & 16.4 \\
Single parent family & 13.5 & 1.4 & 1.0 & 19,9 & 2.6 & 3.9 \\
One person household & 1.8 & 0.9 & 0.3 & 3.0 & 1.1 & 0.7 \\
Other & 4.5 & 2.7 & 2.1 & 6.1 & 2.3 & 5.0 \\
Average & & & & & & \\
\hline Persons: & 1.1 & 3.6 & 3.2 & 0.7 & 2.1 & 7.0 \\
Family with children & 8.6 & 11.3 & 9.3 & 4.8 & 8.1 & 17.5 \\
Single parent family & 13.5 & 1.4 & 1.0 & 19.9 & 2.6 & 3.9 \\
One person household & 1.6 & 0.9 & 0.3 & 2.6 & 1.1 & 0.7 \\
Other & 2.7 & 3.3 & 2.7 & 3.1 & 2.4 & 5.9 \\
Average & &
\end{tabular}

Source: Microcensus 1988, 1992 and 1996 (own computations).

Note:

Legal poverty line: the percentage of households (persons) below the official subsistence minimum. EU poverty line: the percentage of households (persons) below the half average income per equivalent unit (if the first adult is computed as 1.0, each other adult as 0.7 and each child as 0.5).

Table 2 Net replacement rates at the 67 percent level of wage of average production worker by type of household (percent)

\begin{tabular}{lcccccccc}
\hline \multirow{3}{*}{ Country } & \multicolumn{3}{c}{ In the first month of unemployment } & \multicolumn{3}{c}{ In the $60^{\text {th }}$ month of unemployment } \\
\cline { 2 - 9 } & $\begin{array}{c}\text { sin- } \\
\text { gle }\end{array}$ & $\begin{array}{c}\text { married } \\
\text { couple }\end{array}$ & $\begin{array}{c}\text { couple } \\
2 \text { child- } \\
\text { ren }\end{array}$ & $\begin{array}{c}\text { single } \\
\text { 2 child- } \\
\text { ren }\end{array}$ & $\begin{array}{c}\text { sin- } \\
\text { gle }\end{array}$ & $\begin{array}{c}\text { married } \\
\text { couple }\end{array}$ & $\begin{array}{c}\text { couple } \\
2 \text { child- } \\
\text { ren }\end{array}$ & $\begin{array}{c}\text { single } \\
\text { 2 child- } \\
\text { ren }\end{array}$ \\
\hline Czech Republic & 60 & 74 & 76 & 77 & 53 & 91 & 100 & 100 \\
Hungary & 86 & 86 & 90 & 91 & 64 & 64 & 74 & 75 \\
Poland & 49 & 52 & 61 & 58 & 42 & 42 & 51 & 51 \\
Austria & 57 & 62 & 77 & 73 & 54 & 59 & 74 & 70 \\
Belgium & 84 & 76 & 76 & 82 & 78 & 90 & 91 & 98 \\
France & 85 & 85 & 87 & 87 & 57 & 56 & 58 & 60 \\
Germany & 73 & 74 & 76 & 80 & 76 & 87 & 92 & 91 \\
Netherlands & 86 & 90 & 86 & 86 & 85 & 95 & 96 & 94 \\
Spain & 71 & 71 & 73 & 74 & 37 & 47 & 63 & 57 \\
Sweden & 78 & 78 & 85 & 87 & 89 & 116 & 122 & 82 \\
United Kingdom & 75 & 88 & 80 & 63 & 74 & 92 & 96 & 83 \\
United States & 59 & 59 & 50 & 52 & 11 & 18 & 58 & 50 \\
\hline
\end{tabular}

Source: OECD, $1998 b$. 
Table 3 Self-ranking into social class (percent)

\begin{tabular}{lrrrrrr}
\hline Social class & \multicolumn{3}{c}{ All population } & \multicolumn{4}{c}{ Economically active } \\
& 1991 & 1995 & 1999 & 1991 & 1995 & 1999 \\
\hline Lower & 8.7 & 9.9 & 19.9 & 5.7 & 6.1 & 11.3 \\
Lower middle & 27.2 & 24.6 & 35.2 & 30.3 & 22.6 & 39.4 \\
Middle & 61.1 & 60.2 & 38.8 & 61.0 & 64.9 & 42.1 \\
Upper middle & 3.0 & 5.3 & 6.8 & 3.1 & 6.4 & 7.2 \\
Total (average) & 100.0 & 100.0 & 100.0 & 100.0 & 100.0 & 100.0 \\
\hline
\end{tabular}

Source: Surveys on Social Justice (own computations).

Table 4 Possession of shares and perceived personal gain of voucher privatization (percent of affirmative answers)

\begin{tabular}{lcccccr}
\hline Social class & \multicolumn{3}{c}{ All population } & \multicolumn{3}{c}{ Economically active } \\
& 1 & 2 & 3 & 1 & 2 & 3 \\
\hline Lower & 9.5 & 21.0 & 27.8 & 19.4 & 19.4 & 27.2 \\
Lower middle & 25.8 & 32.9 & 42.0 & 34.4 & 34.4 & 43.2 \\
Middle & 36.8 & 43.8 & 50.5 & 46.5 & 46.5 & 51.5 \\
Upper middle & 61.8 & 49.4 & 68.2 & 54.9 & 54.9 & 74.6 \\
Total (average) & 30.1 & 36.5 & 44.9 & 33.1 & 39.8 & 47.8 \\
\hline
\end{tabular}

Source: Economic Expectations and Attitudes, April 1998 (own computations).

Questions:

1 Do you own some company shares?

2 Do you own some IPF shares?

3 Would you today resume that you profited from voucher privatization? 
Figure 1 Average wage and pension benefit in 1990-1999 (constant prices of 1989)

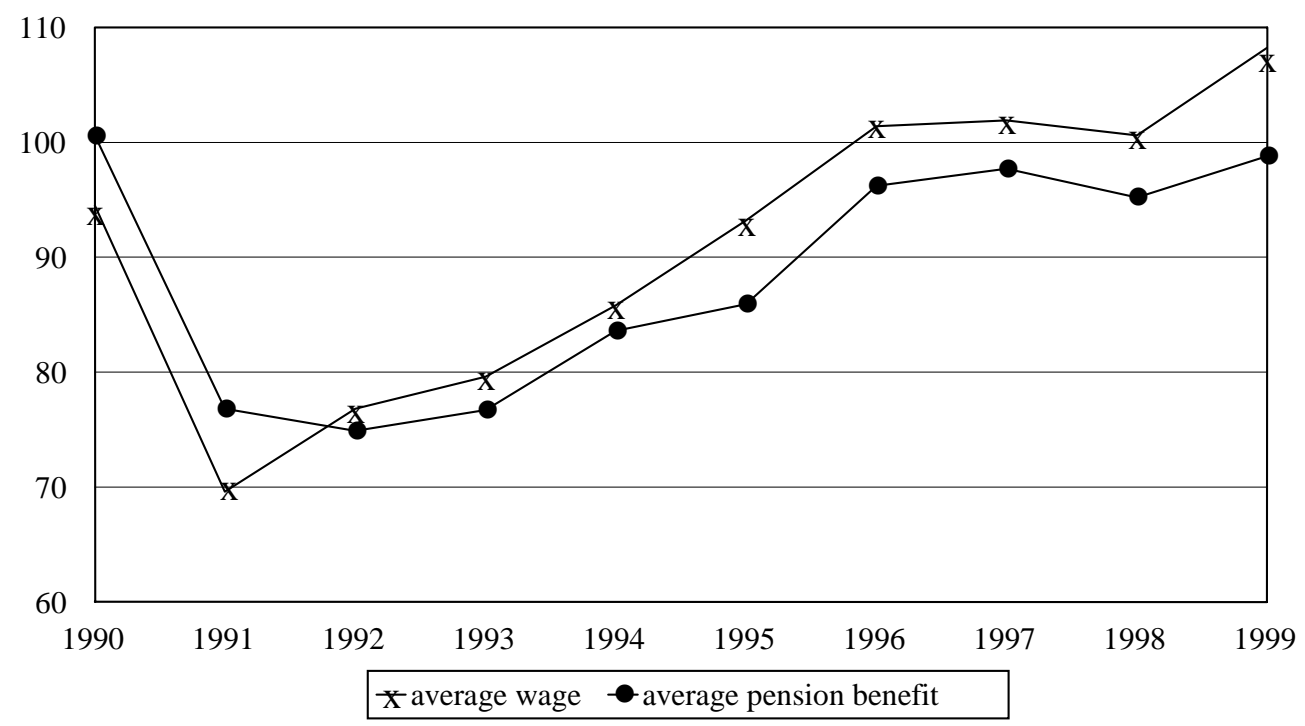

Source: Statistical Yearbooks of the Czech Republic.

Figure 2 Subsistence minimum and wage levels around 1999

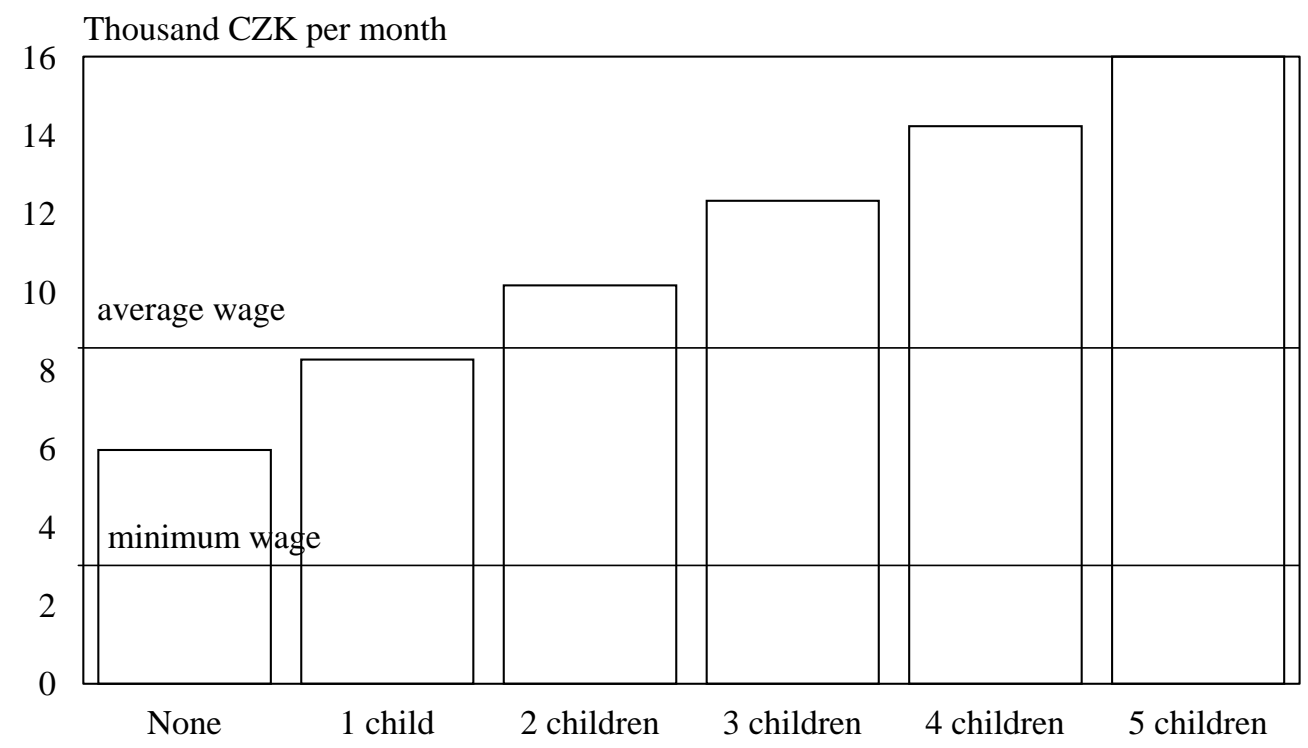

Source: Ministry of Labor and Social Affairs. 
Figure 3 Payroll tax in OECD countries around 1996

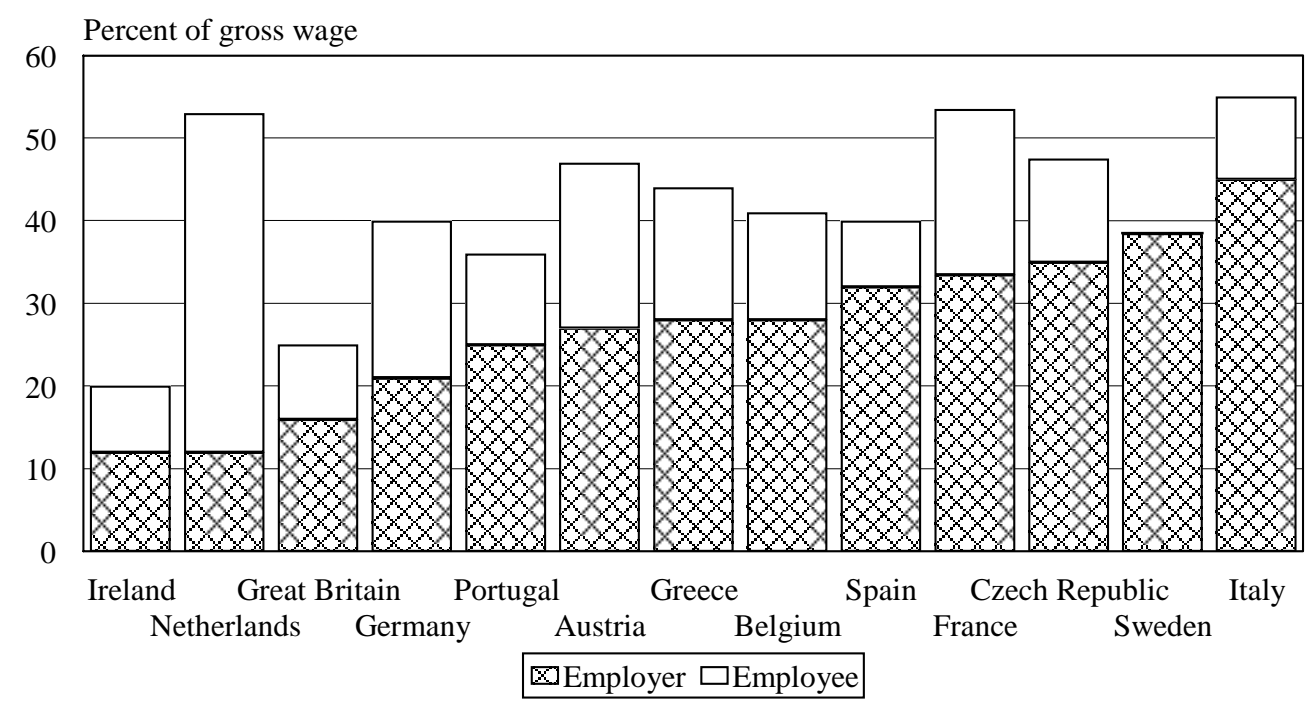

Source: OECD, 1997.

Figure 4 Total wages paid in tertiary branches in 1990-1999 (constant prices of 1989)

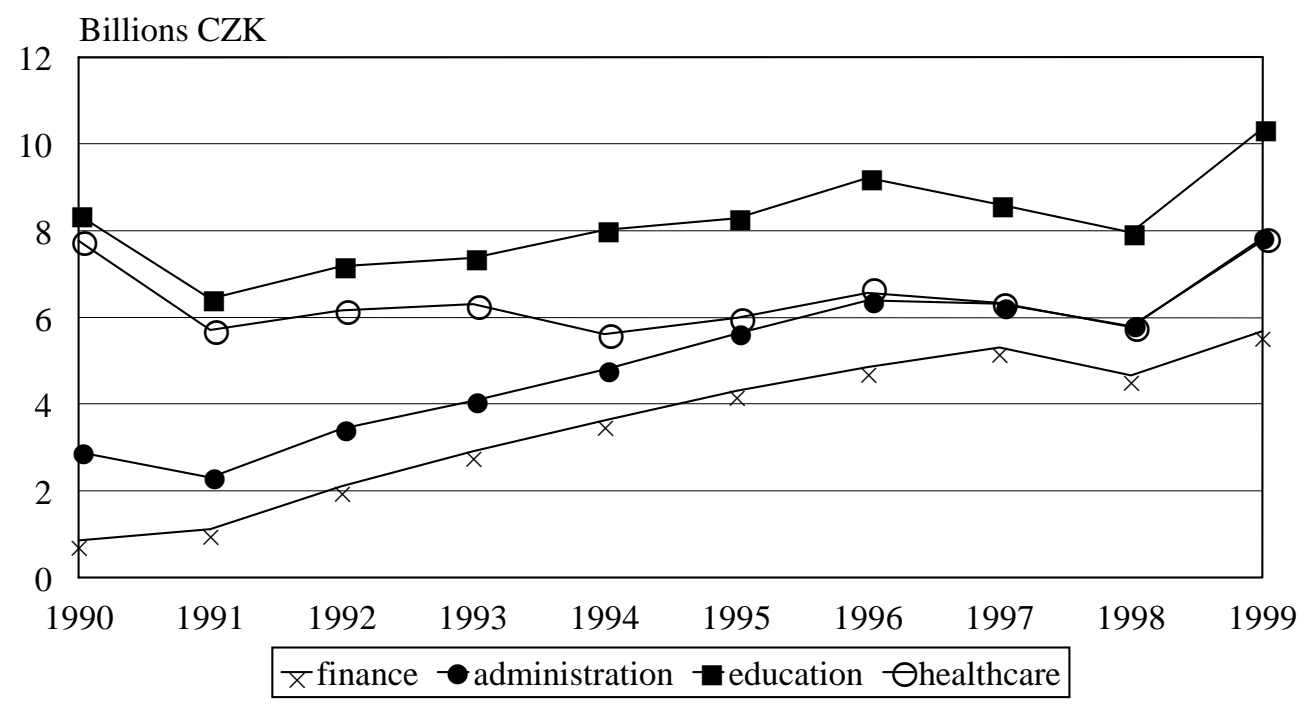

Source: Statistical Yearbooks of the Czech Republic. 


\section{DAVIDSON INSTITUTE WORKING PAPER SERIES - Most Recent Papers}

The entire Working Paper Series may be downloaded free of charge at: www.wdi.bus.umich.edu

CURRENT AS OF 11/15/01

\begin{tabular}{|c|c|c|}
\hline Publication & Authors & Date \\
\hline $\begin{array}{l}\text { No. 404: Social Policies and Structures: Institutional Frictions and Traps } \\
\text { in the Czech Republic after } 1989\end{array}$ & Jiří Večerník & Nov. 2001 \\
\hline $\begin{array}{l}\text { No. 403: Investment, Efficiency, and Credit Rationing: Evidence from } \\
\text { Hungarian Panel Data }\end{array}$ & Mathilde Maurel & Nov. 2001 \\
\hline $\begin{array}{l}\text { No. 402: Subduing High Inflation in Romania. How to Better Monetary } \\
\text { and Exchange Rate Mechanisms? }\end{array}$ & $\begin{array}{l}\text { Daniel Daianu and Radu } \\
\text { Vranceanu }\end{array}$ & Aug. 2001 \\
\hline $\begin{array}{l}\text { No. 401: The Gender Wage Gap in Bulgaria: A Semiparametric } \\
\text { Estimation of Discrimination }\end{array}$ & Dean Jolliffe & July 2001 \\
\hline $\begin{array}{l}\text { No. 400: Do External Auditors Perform a Corporate Governance Role in } \\
\text { Emerging Markets? Evidence from East Asia }\end{array}$ & Joseph P. H. Fan and T.J. Wong & Oct. 2001 \\
\hline $\begin{array}{l}\text { No. 399: Financial Conditions and Investment during the Transition: } \\
\text { Evidence from Czech Firms }\end{array}$ & Lubomír Lízal and Jan Svejnar & Oct. 2001 \\
\hline $\begin{array}{l}\text { No. 398: Accessible Pareto-Improvements: Using Market Information to } \\
\text { Reform Inefficiencies }\end{array}$ & Michael Mandler & May 2001 \\
\hline No. 397: The Making of an Integrated National Grain Market in China & Wubiao Zhou & Oct. 2001 \\
\hline No. 396: Corruption and Resource Allocation: Evidence from China & Wei Li & June 2001 \\
\hline $\begin{array}{l}\text { No. 395: Government Shareholding and the Value of China's Modern } \\
\text { Firms }\end{array}$ & Lihui Tian & Apr. 2001 \\
\hline No. 394: Labor Hoarding in Russia: Where Does it Come from? & $\begin{array}{l}\text { Rouslan Koumakhov and Boris } \\
\text { Najman }\end{array}$ & June 2000 \\
\hline $\begin{array}{l}\text { No. 393: Ownership Structure, Corporate Governance, And Firm Value: } \\
\text { Evidence from the East Asian Financial Crisis }\end{array}$ & Michael Lemmon and Karl Lins & Apr. 2001 \\
\hline No. 392: Marshall and Labour Demand in Russia: Going Back to Basics & $\begin{array}{l}\text { Jozef Konings and Hartmut } \\
\text { Lehmann }\end{array}$ & Aug. 2001 \\
\hline No. 391: Economic Transition and Elections in Poland & $\begin{array}{l}\text { John E. Jackson, Jacek Klich, and } \\
\text { Krystyna Poznańska }\end{array}$ & June 2001 \\
\hline $\begin{array}{l}\text { No. 390: Effects of Bank Insolvency and Strategic Uncertainty on } \\
\text { Corporate Restructuring in Transition Economies }\end{array}$ & Christa Hainz & Aug. 2001 \\
\hline No. 389: Mark-Up Pricing In Bulgarian Manufacturing & $\begin{array}{l}\text { Rumen Dobrinsky, Boyko } \\
\text { Nikolov, and Nikolay Markov }\end{array}$ & June 2001 \\
\hline $\begin{array}{l}\text { No. 388: Globalization and Firms' Financing Choices: } \\
\text { Evidence from Emerging Economies }\end{array}$ & $\begin{array}{l}\text { Sergio Schmukler and Esteban } \\
\text { Vesperoni }\end{array}$ & May 2001 \\
\hline $\begin{array}{l}\text { No. 387: The Distributional Impacts of Indonesia's Financial Crisis on } \\
\text { Household Welfare: A "Rapid Response" Methodology }\end{array}$ & $\begin{array}{l}\text { Jed Friedman and James } \\
\text { Levinsohn }\end{array}$ & Sept. 2001 \\
\hline $\begin{array}{l}\text { No. 386: Corporate Financial Policies and Performance Prior to Currency } \\
\text { Crises }\end{array}$ & $\begin{array}{l}\text { Arturo Bris, Yrjö Koskinen, and } \\
\text { Vicente Pons }\end{array}$ & June 2001 \\
\hline No. 385: Ownership and Productive Efficiency: Evidence from Estonia & Derek C. Jones and Niels Mygind & Aug. 2001 \\
\hline $\begin{array}{l}\text { No. 384: Forthcoming in: Journal of Economic Perspectives, } \\
\text { "Institutional Determinants of Labor Reallocation in Transition" Vol. } \\
\text { 16, No. 2, Feb. } 2002 .\end{array}$ & Tito Boeri and Katherine Terrell & June 2001 \\
\hline $\begin{array}{l}\text { No. 383: Deindustrialisation and Structural Change During the Post- } \\
\text { Communist Transition }\end{array}$ & $\begin{array}{l}\text { Tomasz Mickiewicz and Anna } \\
\text { Zalewska }\end{array}$ & June 2001 \\
\hline No. 382: Markets and Growth & Štěpán Jurajda and Janet Mitchell & July 2001 \\
\hline $\begin{array}{l}\text { No. 381: Labor Market Discrimination During Post-Communist } \\
\text { Transition: A Monopsony Approach to the Status of Latvia's Russian } \\
\text { Minority }\end{array}$ & Robert S. Chase & Sept. 2000 \\
\hline No. 380: Dollarization of Liabilities in Non-tradable Goods Sector & Frédéric Chabellard & June 2001 \\
\hline $\begin{array}{l}\text { No. 379: Lessons from the Russian Meltdown: The Economics of Soft } \\
\text { Legal Constraints }\end{array}$ & Enrico Perotti & Mar. 2001 \\
\hline
\end{tabular}

